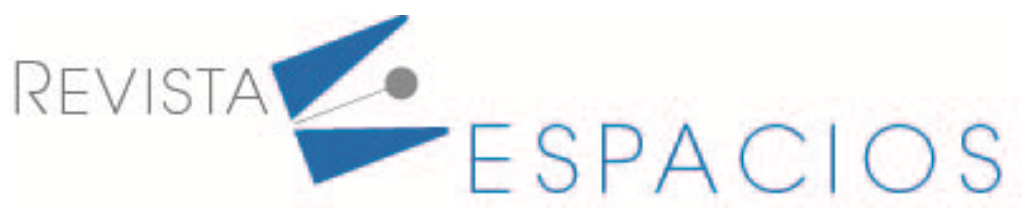

\title{
Development and validation of a nursing instrument for triage in occupational health services
}

\section{Elaboración y validación de un instrumento de enfermería para triaje en servicios de salud ocupacional}

\author{
CARIBÉ, Janaína S. ${ }^{1}$ \\ VITERBO, Lilian M. F. ${ }^{2}$ \\ VIDAL, Diogo G. ${ }^{3}$ \\ SÁ, Kátia N. ${ }^{4}$
}

\begin{abstract}
This study aimed to develop and validate an instrument for nursing triage in occupational health services (ICEST). Exploratory factor-analysis techniques were used to remove redundant or non-endorsed items and identify the factor structure of the ICEST. Validation of the items, content, construct and reliability were also performed. The final ICEST consisted of 14 indicators and 71-graduated indexes. The ICEST showed to be reliable, consistent and satisfactory structure to be applied in occupational health services.

keywords: validation studies; occupational health; nursing

\section{Resumen}

Este estudio tiene como objetivo desarrollar y validar un instrumento para el triaje de enfermería en los servicios de salud ocupacional (ICEST). Se utilizaron técnicas de análisis de factores exploratorios para eliminar los elementos redundantes o no respaldados e identificar la estructura de factores del ICEST. También se realizó la validación de los elementos, el contenido, la construcción y la fiabilidad. El ICEST final consistió en 14 indicadores y 71 índices graduados. EI ICEST demostró ser una estructura fiable, coherente y satisfactoria que se aplicará en los servicios de salud ocupacional.

Palabras clave: estudios de validación; salud ocupacional; enfermería
\end{abstract}

\section{Introduction}

Occupational health is a segment of public health that intends to ensure safety, wellbeing, and hygiene in the workplace, with special attention to workers (Portaria MS/GM n. 1823 de 23 de Agosto de 2012. Institutes the National Worker's and Worker's Health Policy, 2012). The workplace has to be seen as a potential setting to develop several health problems including orthopaedic and mental disorders (Nilsen \& Bernhardsson, 2019). Occupational Health Services (OHS) handle professional potential risks, surveillance and health promotion to workers (Lacaz, 1997). In Brazil, numerous activities of OHS are supported by the Organic Law of Health number 8,080 from 19 September 1990 (Law No. 8,080 of 19 September 1990. Provides the Conditions for the Promotion,

\footnotetext{
${ }^{1}$ Emergency Nurse. Salvador City Hall, Bahia, Brazil. nanicaribe@yahoo.com.br

${ }^{2}$ Researcher and PhD Student. UFP Energy, Environment and Health Research Unit. University Fernando Pessoa. lilianmferrari@gmail.com

${ }^{3}$ Researcher and PhD Student. UFP Energy, Environment and Health Research Unit. University Fernando Pessoa. diogoguedesvidal@hotmail.com

${ }^{4}$ Associate Professor. Research and Post Graduation Department. Bahiana School of Medicine and Public Health. katia.sa@gmail.com
} 
Protection and Recovery of Health, the Organization and Operation of the Corresponding Services and Provides Other Measures, 1990).

The Occupational Health Surveillance understands a continuous and systematic performance, over time, to detect, know, research and analyse the determinants and conditioning factors of health problems related to work processes and environments (Vianna et al., 2017). It is also seen as a capable intervention in the factors that determine the workers' health problems (Vasconcellos, 2018).

An interdisciplinary team including work Engineers, Security Technics, Physicians, Psychologists, Physiotherapists, Occupational Therapists, Physical Educators, and Nurses develop these activities (Ordem dos Enfermeiros, 2014). However, each professional has their own diagnostic (structural, ergonomics, clinical, functional, psychological), proper assessment instruments (validated questionnaires, scales and equipment), except nursing (Refers the Systematization of Nursing Care and the Implementation of the Nursing Process in Public or Private Environments, in Which Nursing Professional Care Occurs, and Provides Other Measures, 2009).

Nurse responsibility in the interdisciplinary health team in the occupational setting is to participate actively as an important member. Since nurses promote a point of view about the social determinants of health in their university formation (Ortega et al., 2015), is their obligation to contribute with their knowledge to the health team. At the workplace, physicians give a clinical diagnostic (Silva et al., 2010), physiotherapist (Spoto \& Collins, 2008), occupational therapists (Rogers \& Holm, 1991) and physical educators (Jiandani \& Mhatre, 2018) use their specifics functional diagnostic, engineers measure the risks (Antonio \& Lacaz, 2007; Paiva et al., 2013), and psychologists give mental and behaviour disorders diagnostic (Johnstone, 2017). Nurses must use their proper knowledge to contribute to the interdisciplinary diagnostic on the integral health opinion.

Innovative practices in work nursing are necessary to improve fields of action and to overcoming simplistic and little reflective practices. The complex relationship between work and health is necessary to understand in a wider perspective (Alshehry et al., 2019; Viterbo, Silva, et al., 2019). Systematic records about social and other aspects made by nurses can be useful for more complete information that provides the basis for effective actions for the workers' promotion, prevention, assessment, treatment and rehabilitation (Law No. 8,080 of 19 September 1990. Provides the Conditions for the Promotion, Protection and Recovery of Health, the Organization and Operation of the Corresponding Services and Provides Other Measures, 1990). The good practice guidelines in health suggest clarifying hypotheses and questions. This means providing a picture, noticing what is missing, prioritizing issues, selecting and planning interventions, minimizing bias by choices and decisions explicit, framing interventions, predicting responses and thinking about lack of progress. This will help the service user to feel understood and contained, and strengthening the therapeutic alliance (Spoto \& Collins, 2008). All of those actions require the nurses' attention to find what a proper lack to be completed by nurses. Some aspects about workers health as a lifestyle, social network, educational level, food habits, familial conditions, work factors, sanitary environment, habitation and others require a trained view (Paiva et al., 2013). Compromised with actions, equity, and evidence, nurses need to use tools and data to contribute to the workers' health.

In Brazil, work nurse is a regulated speciality in nursing by Federal Council of Nursing according to Resolution number 358/2009 (Refers the Systematization of Nursing Care and the Implementation of the Nursing Process in Public or Private Environments, in Which Nursing Professional Care Occurs, and Provides Other Measures, 2009), but this practice is not consolidated yet. Therefore, the nursing consultation needs to be done with a critical view and based on specific nursing tools and priority interventions. Nursing studs in its regular curriculum formation a proper diagnostic triage involving primary attention to health (Ortega et al., 2015), but fail to have a guiding tool for nursing actions. This study aimed to develop and validate an instrument for nursing triage in occupational health services. 


\section{Methodology}

\subsection{Study design}

Instrument development and validation study for nursing triage in occupational health services. The project was submitted and approved by the Ethical Committee of Bahiana School of Medicine and Public Health (CAAE 73271517.7.00005544). Study participants signed the informed consent form after knowing the risks and benefits. All research procedures are in accordance to 466/12 Resolution of National Brazilian Health Council and Helsinki declaration about ethics in research involving human participants (Approves Regulatory Norms of Research Involving Human Beings; National Health Council Resolution N 466 of December 12, 2012, 2012).

The study was developed between March 2017 and October 2018, with the following stages: i) Analysis of the current Nursing Consultation structure and aspects of worker health addressed; ii) Instrument development by workers nurses; iii) ICEST validity assessment by the Judges Committee; iiii) and item analysis, factor analysis, internal consistency and construct validity, applied in the worker's health service, Bahia, Brazil. Figure 1 presents the ICEST development and validation process.

Figure 1

Flow chart of elaboration and validation process of Instrumento de triagem para Consulta de Enfermagem em Saúde do Trabalhador - ICEST.

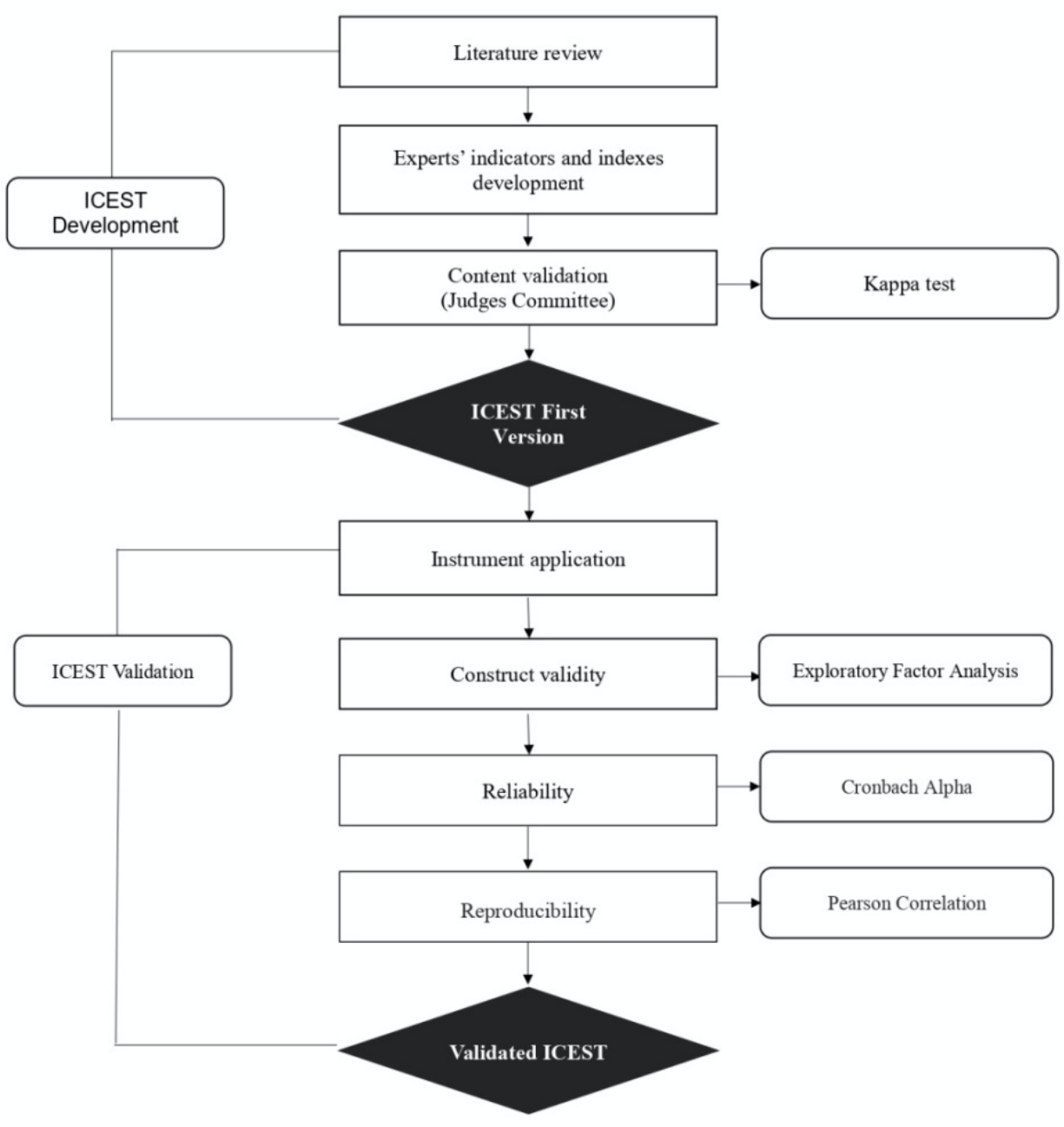

Source: Elaborated by the authors 
A total of 718 medical records of Bahia oil industry workers were included. Prevailed male workers (91.2 \%), with age range 50-59 years old (44.3\%). Remain workers age range is 30-39 year old (25.8\%) and bellows 29 years old (4.2\%). The majority are married (55.4\%) or single (37.2\%). Regarding education level, $64.5 \%$ holds a complete middle school level and $20 \%$ a university level.

\subsection{Instrument development}

Four occupational work nurses with an expert in occupational health services by a minimum of five years participate in this stage. A preliminary literature review about pre-existed instruments and methods was presented to the expert committee with the first version. The ICEST was elaborated with 10 indicators distributed in 3 dimensions with five options ( 0 to 4 points) in a scale: 0 -inexistent; 1 - bad; 2 - reasonable; 3 - good; and 4 - optimal.

From this first instrument version were created 15 indicators including 75-graduated indexes: (1) Work-Related Absenteeism; (2) Work Accident; (3) Social and Recreation Aspects; (4) Environmental Sanitary Conditions; (5) Noise Exposure; (6) Self-Care level; (7) Pests and Vectors; (8) Quality of Water Bottled; (9) Quality of Drinking Water; (10) Air quality; (11) Family Relationships; (12) Health Waste; (13) Chemical Waste; (14) Ergonomics Risk - Physical Aspects; (15) Ergonomics Risk - Organizational Aspects.

A judges committee composed by experts occupational nurses evaluated the first version named Instrumento de triagem para Consulta de Enfermagem em Saúde do Trabalhador [Nursing Instrument for Triage in Occupational Health Services] (ICEST). The ICEST was accompanied by an instruction manual with a questionnaire about relevance, pertinence and clear of items. The experts suggest improving the instrument for a second version.

\subsection{Instrument validation}

Item analysis was performed by the calculation of descriptive statistics and item-total and inter-item correlations ( $r$, Pearson's product-moment correlation) (Hair et al., 2014). Exploratory factor analysis was run to remove redundant or non-endorsed items and identify the factor structure of the instrument (Hair et al., 2014). The internal consistency reliability was assessed by the Cronbach's coefficient alpha (a) and by the Pearson correlations among dimensions extracted by the factor analysis. These steps are described in the literature as the common use to validate instruments (Bonato et al., 2020; Nora et al., 2020; Oliveira et al., 2019; Viterbo, Dinis, Costa, et al., 2019; Viterbo et al., 2020). All statistical tests were performed by IBM ${ }^{\circledR}$ SPSS $^{\circledR}$ Statistics vs.25.0 (IBM Corporation, 2018).

\section{Results}

The characteristics of workers are presented in Table 1.

Table 1

\begin{tabular}{|c|c|c|}
\hline Variable & $\mathbf{N}$ & $\%$ \\
\hline \multicolumn{3}{|l|}{ Sex } \\
\hline Male & 655 & 91.2 \\
\hline Female & 63 & 8.8 \\
\hline \multicolumn{3}{|l|}{ Age } \\
\hline$>60$ & 33 & 4.6 \\
\hline $50-59$ & 318 & 44.3 \\
\hline $40-49$ & 152 & 21.2 \\
\hline $30-39$ & 185 & 25.8 \\
\hline$<29$ & 30 & 4.2 \\
\hline
\end{tabular}




\begin{tabular}{lcc}
\hline Marital Status & & \\
Divorced & 30 & 4.2 \\
Single & 267 & 37.2 \\
Stable union & 21 & 2.9 \\
$\begin{array}{l}\text { Married } \\
\text { Other }\end{array}$ & 398 & 55.4 \\
\hline $\begin{array}{l}\text { Education Level } \\
\text { Incomplete }\end{array}$ & 2 & 0.3 \\
$\begin{array}{l}\text { medium level } \\
\text { Complete } \\
\text { medium level }\end{array}$ & 57 & 9.1 \\
$\begin{array}{l}\text { Incomplete } \\
\text { university level }\end{array}$ & 2 & 64.5 \\
$\begin{array}{l}\text { Complete } \\
\text { university level } \\
\text { University level } \\
\text { with post- } \\
\text { graduation }\end{array}$ & 125 & 0.3 \\
\hline \multicolumn{1}{c}{ Source: Authors elaboration } \\
\hline Total
\end{tabular}

The first version of the ICEST chose by expert nurses included social determinants of health according to World Health Organization guidelines as presented in Table 2.

Table 2

Percentage of interobserver agreement by indicators - Judges Committee

\begin{tabular}{|c|c|c|c|c|}
\hline & $\begin{array}{l}\text { Relevance } \\
\text { level }\end{array}$ & $\begin{array}{l}\text { Relevance } \\
\text { of the } \\
\text { description } \\
\text { of each } \\
\text { index }\end{array}$ & $\begin{array}{l}\text { Statement } \\
\text { coherence }\end{array}$ & $\begin{array}{c}\text { Indicator } \\
\text { Clarity }\end{array}$ \\
\hline Indicator & (\%) & (\%) & (\%) & (\%) \\
\hline 1 Personal Factors & 100 & 50 & 100 & 75 \\
\hline 2 Environmental Components & 100 & 75 & 100 & 75 \\
\hline 3 Exposure to risk agents & 100 & 50 & 50 & 50 \\
\hline 4 Ergonomics - physical environment & 100 & 75 & 100 & 75 \\
\hline 5 Ergonomics - organizational aspects & 100 & 50 & 75 & 50 \\
\hline 6 Health Surveillance & 100 & 75 & 75 & 75 \\
\hline 7 Family relationships & 100 & 100 & 100 & 100 \\
\hline 8 Social Aspects & 100 & 100 & 100 & 100 \\
\hline 9 Immunization & 100 & 100 & 100 & 100 \\
\hline 10 Self-care level & 100 & 100 & 100 & 100 \\
\hline
\end{tabular}

Source: Authors elaboration.

Concordance between judges of pertinence was $100 \%$ to the four indicators (Family Relationships, Social Aspects, Immunization, and Self Care). Personal Factors and Exposition to Risk Agents, Ergonomic and Organizational Aspects have shown 50\% of concordance. Ergonomic and Organizational Aspects and Surveillance presented $75 \%$ of concordance, and Risk Agents 50\%. About clarity, Family Relationships, Social Aspects, Immunization and Self Care presented $100 \%$ of concordance, while Personal Factors, Environmental Components, Ergonomics Factors and Surveillance had $75 \%$, and Risk Agents $50 \%$ of concordance. Items that presented concordance less than $75 \%$ were adjusted. 
Table 3 presents the results of the Pearson correlations among items.

Table 3

Pearson correlations among ítems

\begin{tabular}{|c|c|c|c|c|c|c|c|c|c|c|c|c|c|c|}
\hline Items & 1 & 2 & 3 & 4 & 5 & 6 & 7 & 8 & 9 & 10 & 11 & 12 & 13 & 14 \\
\hline 1.Noise exposure & 1 & & & & & & & & & & & & & \\
\hline $\begin{array}{l}\text { 2.Ergonomic risks - } \\
\text { physical aspects }\end{array}$ & 0.060 & 1 & & & & & & & & & & & & \\
\hline $\begin{array}{l}\text { 3.Ergonomic risks - } \\
\text { organizational aspects }\end{array}$ & 0.011 & 0.059 & 1 & & & & & & & & & & & \\
\hline $\begin{array}{l}\text { 4.Sanitary conditions of } \\
\text { work environment }\end{array}$ & 0.003 & $0.171^{* *}$ & $0.109^{* *}$ & 1 & & & & & & & & & & \\
\hline 5.Chemical waste & -0.059 & -0.028 & -0.012 & 0.023 & 1 & & & & & & & & & \\
\hline 6. Pests and vectors & 0.067 & $0.240^{* *}$ & -0.001 & $0.157^{* *}$ & -0.051 & 1 & & & & & & & & \\
\hline 7.Air quality & 0.020 & $0.177^{* *}$ & 0.062 & $0.106^{* *}$ & -0.038 & $0.691^{* *}$ & 1 & & & & & & & \\
\hline 8.Quality of bottled water & -0.022 & $-0.109^{* *}$ & 0.004 & -0.068 & 0.032 & $-0.508^{* *}$ & $-0.629^{* *}$ & 1 & & & & & & \\
\hline $\begin{array}{l}\text { 9.Quality of drinking } \\
\text { water }\end{array}$ & 0.027 & 0.008 & 0.054 & 0.029 & -0.051 & $0.245^{* *}$ & $0.522^{* *}$ & $-0.276^{* *}$ & 1 & & & & & \\
\hline $\begin{array}{l}\text { 10.Work-relate } \\
\text { absenteism }\end{array}$ & -0.031 & 0.009 & 0.072 & 0.030 & 0.035 & 0.010 & -0.037 & 0.017 & -0.023 & 1 & & & & \\
\hline 11.Work accident & 0.030 & 0.013 & $0.107^{* *}$ & 0.016 & -0.011 & -0.032 & 0.021 & -0.033 & 0.043 & $0.178^{* *}$ & & & & \\
\hline 12.Family relationships & 0.021 & 0.000 & 0.027 & $0.090^{*}$ & -0.008 & 0.020 & 0.005 & -0.070 & -0.017 & 0.030 & 0.001 & 1 & & \\
\hline 13.Social aspects - leisure & 0.029 & -0.027 & 0.071 & 0.044 & 0.001 & $-0.079^{*}$ & -0.054 & 0.043 & -0.056 & -0.017 & $0.080^{*}$ & $0.090^{*}$ & 1 & \\
\hline 14.Self-care level & -0.046 & -0.039 & -0.032 & $-0.098^{* *}$ & -0.001 & -0.007 & 0.001 & 0.002 & 0.011 & -0.045 & 0.013 & -0.006 & 0.038 & 1 \\
\hline
\end{tabular}

Notes: *correlation significant at 0.05 level; **correlation significant at 0.01 level.

Source: Authors elaboration

It was noted moderated positive correlations between "Pests and Vectors" and "Quality of Air" $(r=0.691 ; p<0.01)$; and "Quality of Drinking Water" and "Air quality" $(r=0.522 ; p<0.01)$. An inverse correlation was observed between "Pests and Vectors" and "Quality of Bottled Water" ( $r=-0.508 ; p<0.01)$ and "Air quality" and "Quality of Bottled Water" ( $r=-0.629 ; p<0.01)$.

Exploratory factor analysis to identify the construct structure was performed considering the Kaiser-Meyer-Olkin Measure of Sampling Adequacy (KMO = 0.643) values as cut-point, as shown in Table 4.

Table 4

Factor loadings and internal consistency of the ICEST

\begin{tabular}{llc}
\hline Factors & ICEST Items & $\begin{array}{c}\text { Factor } \\
\text { loadings }\end{array}$ \\
\hline $\begin{array}{l}\text { Environmental Aspects } \\
\alpha=0.83\end{array}$ & Pests and vectors & 0.764 \\
$17.5 \%$ & Air quality & 0.919 \\
& Quality of bottled water & 0.782 \\
Occupational Risks & Quality of drinking water & 0.610 \\
$\alpha=0.93$ & Ergonomic risks - Physical aspects & 0.632 \\
$9.1 \%$ & Sanitary conditions of work environment & 0.669 \\
\hline Organizational Risks & Ergonomic risks - Organizational aspects & 0.558 \\
$\alpha=0.70$ & Work accident & 0.727 \\
$8.8 \%$ & Work-related absenteeism & 0.480 \\
\hline Social Aspects & Social aspects - leisure & 0.683
\end{tabular}




\begin{tabular}{lll}
$\alpha=0.82$ & Self-care level & 0.498 \\
$8.2 \%$ & Family relationships & 0.546 \\
\hline Waste and Exposure & Chemical waste & 0.650 \\
$\alpha=0.79$ & Noise exposure & 0.627 \\
$8.1 \%$ & & \\
\hline
\end{tabular}

Note: Extraction method - Principal components. Varimax rotation with Keiser normalization.

Extraction criterion: Eigenvalues $>1$. Total variance explained by extracted components: $51.7 \%$; $\mathrm{KMO}=0.643$;

Bartlett's test: $\chi 2=7064.2, p<0.001 ; C$ - Communalities; Global ICEST Cronbach's alpha: $\alpha=0.90$.

Source: Authors elaboration.

Sampling Adequacy Measures considered values $>0.5$. Because of this, the "Health Waste" was removed from the final model. Table 5 presents the results of the Pearson correlations among extracted factors and ICEST.

Table 5

Pearson correlations among

extracted factors and ICEST

\begin{tabular}{|c|c|c|c|c|c|c|}
\hline Factors & ICEST & $\begin{array}{c}\text { Environmental } \\
\text { Aspects }\end{array}$ & Occupational Risks & Organizational Risks & Social Aspects & $\begin{array}{c}\text { Waste and } \\
\text { Exposure }\end{array}$ \\
\hline ICEST & 1 & & & & & \\
\hline $\begin{array}{l}\text { Environmental } \\
\text { Aspects }\end{array}$ & $0.611^{* *}$ & 1 & & & & \\
\hline Occupational Risks & $0.508^{* *}$ & $0.111^{* *}$ & 1 & & & \\
\hline Organizational Risks & $0.410^{* *}$ & 0.009 & 0.040 & 1 & & \\
\hline Social Aspects & $0.396^{* *}$ & $0.082^{*}$ & 0.016 & $0.393^{* *}$ & 1 & \\
\hline Waste and Exposure & $0.353^{* *}$ & $0.181^{* *}$ & 0.005 & $0.210^{* *}$ & $0.215^{* *}$ & 1 \\
\hline
\end{tabular}

Notes: *correlation significant at 0.05 level; **correlation significant at 0.01 level.

Source: Authors elaboration.

All items are above 0.40 . The final 5 dimensions, with a total of 14 items explained $51.7 \%$ of the total variance. Factor 1 explains $17.5 \%$ of the total variance and contains 4 items representing environmental aspects related to pests and vectors, air quality, quality of bottled water and drinking water. Factor 2 explains $9.1 \%$ of the total variance and contains 2 items representing occupational risk related to physical ergonomic risks and sanitary conditions of the work environment. Factor 3 explains $8.8 \%$ of the total variance and contains 3 items representing organizational risks related to organizational ergonomic risks, work accident and work-related absenteeism. Factor 4 explains $8.2 \%$ of the total variance and contains 3 items representing social aspects related to leisure, self-care level and family relationships. Factor 5 explains $8.1 \%$ of the total variance and contains 2 items representing waste and exposure related to chemical waste and noise exposure.

\section{Discussion}

In the present study, some factors of the analysed instrument - ICEST - were relevant in the opinion of judges: Family Relationships, Social Aspects, Immunization, Self-Care level, Ergonomic and Organizational Aspects, and Surveillance. Those factors are according to the social determinants of health (Carrapato et al., 2017; Commission on Social Determinants of Health, 2008; Graham \& White, 2016; Kurbanova \& Anashkina, 2007). However, with a lower agreement between judges, some biological aspects were incorporated into the second version. In practice, there is a need to look at the global instrument to assess workers health to avoid redundant questions used by other professionals of the interdisciplinary team.

Workers heath is, by its nature, an interdisciplinary and multi-professional field (Antonio \& Lacaz, 2007; Viterbo, Dinis, Vidal, et al., 2019). It was verified that environmental sanitary conditions presented a positive correlation with occupational risks and organizational aspects. This data confirmed the relevance of surveillance in the workplace (Oliveira et al., 2020; Ordem dos Enfermeiros, 2014). Surveillance is a quality proper of nurses 
developed during their professional formation (Ortega et al., 2015), being the best skill in a health team to care about this topic. Besides that, nurses frequently suffer on their skin with incivility in the workplace, causing frustration, harming professional activities and impacting on the quality of life (Alshehry et al., 2019).

The correlation observed between items of the final version of ICEST aggregates dimensions frequently included in the nursing view. Workers health can be considered a valuable asset to society, individual, company and country (Carvalho et al., 2013). It guarantees the worker wellbeing, but also productivity and quality of a company.

A healthy workplace is a place where everyone works together to achieve an agreed vision for the health and wellbeing of workers and the surrounding community (World Health Organization, 2010). It provides all members of the workforce with physical, psychological, social and organizational conditions that protect and promote health and safety. It enables managers and workers to increase control over their health and to improve it, and to become more energetic, positive and contented (Burton, 2010).

One limitation of this study was a non-probabilistic sample, preventing generalization of the results. Due to this limitation, it is necessary to test this instrument in other occupational health services.

\section{Conclusions}

The ICEST is a valid and reliable instrument for nursing triage in occupational health services. As such, it can aid in the identification and quantification of health risk at the workplace. From the results obtained, the emphasis is necessary to the importance of developing a specific instrument to be used by nurses in the diagnosis of the health of workers according to their perspective. The instrument developed in the present study assesses items with accuracy and precision and may be applied in occupational health services.

\section{Bibliographic references}

Alshehry, A. S., Alquwez, N., Almazan, J., Namis, I. M., Moreno-Lacalle, R. C., \& Cruz, J. P. (2019). Workplace incivility and its influence on professional quality of life among nurses from multicultural background: A cross-sectional study. Journal of Clinical Nursing, 28(13-14), 2553-2564. https://doi.org/10.1111/jocn.14840

Antonio, F., \& Lacaz, D. C. (2007). O campo Saúde do Trabalhador : resgatando conhecimentos e práticas sobre as relações The Workers ' Health fi eld : reclaiming knowledge and practices in the interface between work and health. Occupational Health, 23(4), 757-766. https://doi.org/10.1590/S0102-311X2007000400003

Bonato, D., Costa, A. S., Viterbo, L. M. F., Vidal, D. G., \& Dinis, M. A. P. (2020). Medical Emergency Resource Classification Instrument (MERCI) in the Oil Industry, Brazil. In P. M. Arezes, J. S. Baptista, M. P. Barroso, P. Carneiro, P. Cordeiro, N. Costa, R. B. Melo, A. S. Miguel, \& G. Perestrelo (Eds.), Occupational and Environmental Safety and Health II. Studies in Systems, Decision and Control (pp. 247-254). Springer International Publishing. https://doi.org/10.1007/978-3-030-41486-3_27

Approves Regulatory Norms of Research Involving Human Beings; National Health Council Resolution $\mathrm{N}^{\circ} 466$ of December 12, 2012, (2012).

Law No. 8,080 of 19 September 1990. Provides the Conditions for the Promotion, Protection and Recovery of Health, the Organization and Operation of the Corresponding Services and Provides Other Measures, Pub. L. No. Diário Oficial da União (1990). 
Portaria MS/GM n. 1823 de 23 de agosto de 2012. Institutes the National Worker's and Worker's Health Policy, Pub. L. No. Diário Oficial da República Federativa do Brasil (2012).

Burton, J. (2010). WHO Healthy Workplace Framework and Model: Background and Supporting Literature and Practices. World Health Organization. https://www.who.int/occupational_health/healthy_workplace_framework.pdf

Carrapato, P., Correia, P., \& Garcia, B. (2017). Determinante da saúde no Brasil: A procura da equidade na saúde. Saude e Sociedade, 26(3), 676-689. https://doi.org/10.1590/s0104-12902017170304

Carvalho, R. M. B. de, Ogata, A. J. N., Silva, K. B., \& Barbosa, B. T. (2013). Estilo de vida e indicadores organizacionais e de produtividade em uma empresa industrial da Região Nordeste do Brasil. Revista Brasileira de Qualidade de Vida, 5(4), 44-54. https://doi.org/10.3895/s2175-08582013000400006

Commission on Social Determinants of Health. (2008). Closing the gap in a generation: health equity through action on the social determinants of health. https://apps.who.int/iris/bitstream/handle/10665/43943/9789241563703_eng.pdf;jsessionid=A41734C2C 69796C98EA28D15E63331DF?sequence=1

Refers the Systematization of Nursing Care and the Implementation of the Nursing Process in Public or Private Environments, in which Nursing Professional Care occurs, and Provides other Measures, (2009). http://www.cofen.gov.br/resoluo-cofen-3582009_4384.html

Graham, H., \& White, P. C. L. (2016). Social determinants and lifestyles : integrating environmental and public health perspectives. Public Health, 141, 270-278. https://doi.org/10.1016/j.puhe.2016.09.019

Hair, J. F., Black, W. C., Babin, B. J., \& Anderson, R. E. (2014). Multivariate data analysis: Pearson new international edition. Pearson Education Limited.

IBM Corporation. (2018). Released IBM SPSS Statistics for Windows, Versão 25.0 (25.0). IBM Corporation.

Jiandani, M. P., \& Mhatre, B. S. (2018). Physical therapy diagnosis: How is it different? Journal of Postgraduate Medicine, 64(2), 69-72. https://doi.org/10.4103/jpgm.JPGM_691_17

Johnstone, L. (2017). Psychological Formulation as an Alternative to Psychiatric Diagnosis. Journal of Humanistic Psychology, 58(1), 30-46. https://doi.org/10.1177/0022167817722230

Kurbanova, A. G., \& Anashkina, G. A. (2007). A Saúde e seus Determinantes Sociais. PHYSIS: Rev. Saúde Coletiva, 17(2), 77-93.

Lacaz, F. A. de C. (1997). Saúde dos trabalhadores: cenário e desafios. Cadernos de Saúde Pública, 13(suppl 2), S07-S19. https://doi.org/10.1590/s0102-311x1997000600002

Nilsen, P., \& Bernhardsson, S. (2019). Context matters in implementation science: a scoping review of determinant frameworks that describe contextual determinants for implementation outcomes. BMC Health Services Research, 19(1), 189. https://doi.org/10.1186/s12913-019-4015-3

Nora, D., Vidal, D. G., Viterbo, L. M. F., Dinis, M. A. P., \& Sousa, H. F. P. (2020). Motivations Influencing the Surgeon's Healthcare Unit Choice to Perform Surgery: A Confirmatory Study in Portugal. European Journal of Investigation in Health, Psychology and Education, 10(1), 143-158.

https://doi.org/10.3390/ejihpe10010013 
Oliveira, Gisela M, Vidal, D. G., Ferraz, M. P., Cabeda, J. M., Pontes, M., Maia, R. L., Calheiros, J. M., \& Barreira, E. (2019). Measuring Health Vulnerability: An Interdisciplinary Indicator Applied to Mainland Portugal. International Journal of Environmental Research and Public Health, 16(21), 1-18. https://doi.org/10.3390/ijerph16214121

Oliveira, Gisela Marta, Vidal, D. G., Viterbo, L. M. F., Costa, A. S., \& Ferraz, M. P. (2020). Health Monitoring and Intervention Plan on Oil Industry Workers: Results from a Case-Study. In P. M. Arezes, J. S. Baptista, M. P. Barroso, P. Carneiro, P. Cordeiro, N. Costa, R. B. Melo, A. S. Miguel, \& G. Perestrelo (Eds.), Occupational and Environmental Safety and Health II. Studies in Systems, Decision and Control (pp. 265-274). Springer International Publishing. https://doi.org/10.1007/978-3-030-41486-3_29

Ordem dos Enfermeiros. (2014). O Enfermeiro do Trabalho na Gestão de Saúde Ocupacional - do original: The Role of the Occupational Health Nurse in Workplace Health Management. Ordem dos Enfermeiros. https://www.ordemenfermeiros.pt/media/8894/livroenfermagemtrabalhooms_vfinal_proteg.pdf

Ortega, M. del C. B., Cecagno, D., Llor, A. M. S., de Siqueira, H. C. H., Montesinos, M. J. L., \& Soler, L. M. (2015). Formação acadêmica do profissional de enfermagem e sua adequação às atividades de trabalho. Revista Latino-Americana de Enfermagem, 23(3), 404-410. https://doi.org/10.1590/0104-1169.0432.2569

Paiva, R., Mirian, N., \& Araújo, C. De. (2013). Diagnóstico das condições de saúde e segurança no trabalho : um estudo em obras de edificações verticais. Revista Principia, 22, 51-58.

Rogers, J. C., \& Holm, M. B. (1991). Occupational therapy diagnostic reasoning: a component of clinical reasoning. The American Journal of Occupational Therapy : Official Publication of the American Occupational Therapy Association, 45(11), 1045-1053. https://doi.org/10.5014/ajot.45.11.1045

Silva, E. P. da, Cotta, R. M. M., Souza, A. P. de, Minette, L. J., \& Vieira, H. A. N. F. (2010). Diagnóstico das condições de saúde de trabalhadores envolvidos na atividade em extração manual de madeira. Árvore, 34(3), 561-565.

Spoto, M. M., \& Collins, J. (2008). Physiotherapy diagnosis in clinical practice: a survey of orthopaedic certified specialists in the USA. Physiotherapy Research International : The Journal for Researchers and Clinicians in Physical Therapy, 13(1), 31-41. https://doi.org/10.1002/pri.390

Vasconcellos, L. C. F. de. (2018). Vigilância em Saúde do Trabalhador: decálogo para uma tomada de posição. Revista Brasileira de Saúde Ocupacional, 43(suppl 1), 1-9. https://doi.org/10.1590/2317-6369000029517

Vianna, L. C. R., Ferreira, A. P., Vasconcellos, L. C. F. de, Bonfatti, R. J., \& Oliveira, M. H. B. de. (2017). Vigilância em Saúde do Trabalhador: um estudo à luz da Portaria n 3.120/98. Saúde Em Debate, 41(114), 786-800. https://doi.org/10.1590/0103-1104201711409

Viterbo, L. M. F., Dinis, M. A. P., Costa, A. S., \& Vidal, D. G. (2019). Development and Validation of an Interdisciplinary Worker's Health Approach Instrument (IWHAI). International Journal of Environmental Research and Public Health, 16(15), 1-17. https://doi.org/10.3390/ijerph16152803

Viterbo, L. M. F., Dinis, M. A. P., Vidal, D. G., \& Costa, A. S. (2019). Implementation of an Interdisciplinary Approach to Promote Workers Global Health Status in the Oil Industry, Brazil (2006-2015). International Journal of Environmental Research and Public Health, 16(12), 1-16.

https://doi.org/10.3390/ijerph16122148 
Viterbo, L. M. F. L. M. F., Dinis, M. A. P., Sá, K. N., Marques, C. A. S. C., Navarro, M. V. T., \& Leite, H. J. D. (2020). Development of a quantitative instrument for sanitary inspection in food and nutrition services, Brazil. Cien Saude Colet, 25(3), 805-816. https://doi.org/10.1590/1413-81232020253.16372018

Viterbo, L. M. F., Silva, I. B., Leite, J. S. F., Vidal, D. G., Moura, A. de, \& Dinis, M. A. P. (2019). Prevalence of Nursing Diagnostics in Oil Industry Workers in Bahia, Brazil. Revista Enfermagem Contemporânea. https://www5.bahiana.edu.br/index.php/enfermagemissn

World Health Organization. (2010). Healthy workplaces: a model for action: for employers, workers, policymakers and practitioners. In 2019.

https://www.who.int/occupational_health/publications/healthy_workplaces_model_action.pdf

Esta obra está bajo una Licencia Creative Commons Attribución-NoCommercial 4.0 International

\section{(cc) EY-NC}

